\title{
Küçük Hücreli Dışı Akciğer Kanserinde Neoadjuvan ve Adjuvan Tedavi Sonuçları
}

\author{
Neoadjuvant and Adjuvant Treatment Results in Non-Small Cell Lung Cancer \\ Hasret Cengiz ${ }^{1}$, Ayşe Demirci ${ }^{2}$, Ceyhun Varım ${ }^{3}$, Nil Molinas Mandel ${ }^{4}$, Hande Turna ${ }^{5}$ \\ ${ }^{1}$ Sakarya Üniversitesi Eğitim ve Araştırma Hastanesi Endokrinoloji ve Metabolizma Kliniği, Sakarya \\ ${ }^{2}$ Sakarya Üniversitesi Eğitim ve Araştırma Hastanesi Tibbi Onkoloji Kliniği, Sakarya \\ ${ }^{3}$ Sakarya Üniversitesi Eğitim ve Araştırma Hastanesi Iç Hastalıkları Kliniği, Sakarya \\ ${ }^{4}$ Koç Üniversitesi Tip Fakültesi Tibbi Onkoloji Kliniği, İstanbul \\ ${ }^{5}$ İstanbul Üniversitesi Cerrahpaşa Tip Fakültesi Tibbi Onkoloji Kliniği, İstanbul
}

\author{
Yazışma Adresi / Correspondence: \\ Ceyhun Varım \\ Adnan Menderes Caddesi, Sağlık Sokak, No: 195-54000, Adapazarı/Sakarya \\ T: +902642552106 E-mail : ceyhunvarim@sakarya.edu.tr \\ Geliş Tarihi / Received : 17.05.2020 Kabul Tarihi / Accepted : 01.09.2020 \\ Orcid : \\ Hasret Cengiz https://orcid.org/ 0000-0002-5216-3368 \\ Ayșe Demirci https://orcid.org/ 0000-0002-6291-7573 \\ Ceyhun Varım https://orcid.org/ 0000-0002-8369-0857 \\ Nil Molinas Mandel https://orcid.org/ 0000-0002-8837-0756 \\ Hande Turna https://orcid.org/ 0000-0003-0558-9371 \\ ( Sakarya Tip Dergisi / Sakarya Med J 2020, 10(3):450-458) DOI: 10.31832/smj.738807 \\ Bu makale "Hasret CENGİ" tarafindan yazılan uzmanlık tezinin özetidir
}

\footnotetext{
Öz

Amaç Kliniğimize Küçük Hücreli Dışı Akciğer Kanseri (KHDAK) tanısı ile başvuran ve bu tanı ile neoadjuvan ve adjuvan tedavi alan hastaların hastalıksız ve genel sağkalım sonuçlarını değerlendirmek ve erken evre KHDAK'de hasta ve tümör karakteristiklerinin prognoza etkisini belirlemektir.

Gereç ve Kliniğimize Ocak 2005-Haziran 2010 tarihleri arasında başvuran KHDAK hastalarının dosyaları retrospektif olarak taranarak, hasta ve tümör karakteristikleri, hastalıksız Yöntemler ve genel sağkalım verileri, hasta ve tümör özelliklerinin prognoza etkisi incelendi.

Bulgular Neoadjuvan grup 47 hastadan, primer opere olan grup da 135 hastadan olușuyordu. Cisplatin bazlı adjuvan kemoterapi evre III hastalarda hem hastalıksız sağkalım $(\mathrm{p}=0,001)$ ve hem de genel sağkalım $(\mathrm{p}<0,001)$ açısından anlamlı yarar sağlandı. Neoadjuvan tedavi grubunda cevap oranı $\% 25,5$ idi ve $\% 23,4$ hasta opere olabildi. Neoadjuvan tedavi alan evre III grup hastalar aynı evredeki adjuvan grup ile karşılaştırıldığında sağkalım azalması bulunamazken; tedavi sonucunda nodal evresi gerileyip opere olabilmiş hastalarda belirgin sağkalım artısıı saptandı ( $43,9 \pm 5,8$ aya $20,2 \pm 1,7$ ay).

Sonuç Adjuvan kemoterapi sağkalımı sadece evre III hastalarda anlamlı arttırmıştır. Neoadjuvan tedavi eğer mediastinal nodal evreyi geriletiyorsa sağkalım avantajı sağlamıştır. Tümör çapı,vasküler invazyon ve göğüs duvarı invazyonu; hastalıksız ve genel sağkalım açısından önemli tümör karakteristikleri olarak saptanmıștır.

Anahtar Küçük Hücreli Dışı Akciğer Kanseri; Adjuvan Tedavi; Neoadjuvan Tedavi

Kelimeler

Abstract

Objective : In this study we assess our center's neoadjuvant and adjuvant therapy results in terms of disease free and overall survival and determine the effects of patient and tumor characteristics as prognostic factors in patients with early stage Non Small Cell Lung Cancer NSCLC.

Materials Files of 182 patients in stage I-III NSCLC followed up at outpatient Medical Oncology Clinic of Cerrahpasa Medical Faculty, between January 2005 and June 2010 were retrospectively analysed. Files of 182 patients in stage I-III NSCLC followed up at outpatient Medical Oncology Clinic of Cerrahpaşa Medical Faculty, between January 2005 and June 2010 were retrospectively analysed.
Patient and tumor characteristics; disease free and overall survival, the prognostic effects of patient and tumor characteristics on survival were analysed.

Results Neoadjuvant chemotherapy group consisted of 47 patients, however 135 patients had primary surgery and had either received adjuvan chemotherapy or followed-up without therapy. Adjuvant chemotherapy improved disease free survival $(p=0.001)$ and overall survival significantly $(p \otimes 0.001)$ in stage III NSCLC patients. In the neoadjuvant therapy group the response rate was found to be $25.5 \%$ and $23.4 \%$ of patients could be operated. No survival benefit was found between stage III NSCLC patients receiving neoadjuvant chemotherapy or not. The patients who could be operated after neoadjuvant chemotherapy were found to have a longer overall survival than the patients who couldn't. (43.9 \pm 5.8 months vs $20.2 \pm 1.7$ months).

Conclusion Adjuvant chemotherapy improved survival only at stage III. The lack of benefit in stage II, can be due to relatively smaller benefit and inefficient number of patients to show this small benefit at this stage. Neoadjuvant chemotherapy was found beneficial only when it reduced the mediastinal nodal stage. Tumor diameter, vascular invasion and chest wall invasion were found to be the pathological characteristics that have a statistically significant impact in terms of disease free and overall survival.

Keywords Non small cell lung cancer; Adjuvant Therapy; Neoadjuvant Therapy
} 


\section{GIIRIŞ}

Akciğer kanseri; akciğer parankimi ya da hava yollarından kaynaklanan maligniteler için kullanılır. Günümüzde kadın ve erkeklerde, kansere bağlı ölümlerin en başta gelen nedenlerinden biridir. 2018 yılında tüm dünyada 2,1 milyon yeni vaka ortaya çıkmış ve 1,7 milyon kişinin ölümüne sebep olmuştur. ${ }^{1}$

Akciğer kanseri; temel olarak küçük hücreli ve küçük hücreli dışı olarak iki gruba ayrılır. Vakaların \%85’i küçük hücreli dışı akciğer kanseridir (KHDAK). Küçük hücreli dışı akciğer kanserinin de kendi içinde alt tipleri vardır. Bunlardan en sık görülenleri skuamoz hücreli karsinom ve adenokarsinomdur. Erken evrelerde (evre I-II) cerrahi, lokal ileri evrede (evre III) kemoradyoterapi veya seçilmiş olgularda cerrahi, metastatik aşamada (evre IV) ise sistemik kemoterapi, tirozin kinaz inhibitörleri, immünoterapi ve palyatif radyoterapi KHDAK'nin günümüzdeki genel tedavi prensiplerini oluşturur. ${ }^{1}$

Küçük hücreli dışı akciğer kanserli hastalarda, rezeksiyondan sonra, erken evrelerde bile lokal ve sistemik nüksler görülebilmektedir. Erken evre kabul edilip rezeke edilen ve makroskopik hastalığı kalmayan hastaların çoğunda aslında mikroskopik canlı tümör hücreleri mevcuttur. Bu hücreler zamanla çoğalıp makroskopik nüksleri oluşturmaktadır. Hastalığın kontrolünü daha iyi sağlayabilmek için opere olabilen hastalara tamamlayıcı kemoterapi ve radyoterapi verilebilmektedir. Bu tedaviler cerrahi rezeksiyon öncesi verildiğinde neoadjuvan, sonrasında verildiğinde ise adjuvan tedaviler olarak ikiye ayrılmaktadır. Sistemik nüks riski lokal nüks riskinden daha fazladır. Bu durum adjuvan tedavi olarak sistemik kemoterapinin potansiyel olarak daha yararlı olabileceğini düşündürmektedir. Adjuvan kemoterapi ile ilgili çalışmalar özellikle 1995 yılından sonra hızlanmış ve evre II ve III hastalarda sağkalıma katkısı birçok büyük çalışmada gösterilmiştir. Özellikle 2004 yılından sonra Evre II ve IIIA hastalarda cerrahi sonrası adjuvan kemoterapi uygulanması standart haline gelmiştir. Neoadjuvan kemoterapi Evre I ve II hastalarda öneril- mezken; Evre IIIA olgularda neoadjuvan kemoterapi; evresi gerileyip cerrahi rezeksiyona gidebileceği düşünülen hastalara uygulanabilmektedir. ${ }^{1}$

Bu çalışmanın amacı; 2005 yılı ve sonrasında neoadjuvan veya adjuvan tedavi uygulanan erken evre ve lokal ileri (evre I- III) KHDAK hastalarında retrospektif olarak genel sağkalım (GS) ve hastalıksız sağkalım (HS) sürelerini, neoadjuvan veya adjuvan olarak uygulanan tedavilerin sağkalıma katkısını saptayabilmek, nüks eden olgulardaki nüks şekillerini ve tümörün patolojik özelliklerinin prognostik önemini belirleyebilmektir.

\section{GEREÇ ve YÖNTEMLER}

Bu çalışmaya Cerrahpaşa Tıp Fakültesi Medikal Onkoloji Bilim Dalı Polikliniğine 01.01.2005-01.06.2010 tarihleri arasında başvuran hastalardan dosyasına ulaşılabilen Evre I-IIIB KHDAK tanısı almış 25’i kadın toplam 182 hasta alınmıştır. Olguların dosyaları retrospektif olarak taranarak hastaların demografik özellikleri, tümörün histopatolojik özellikleri ve evresi, hastalara uygulanan tedaviler ve yanıtları, nüks durumu ve sağkalım bilgileri kaydedildi. Dosyalardan ulaşılamayan bilgiler ise dosyada veya bilgi işlemde kayıtlı telefonlarından aranarak ulaşılabilen hasta ve hasta yakınları ile yapılan görüşmelerle tamamlandı. Araştırmamız prognostik kohort araştırmasıdır.

Verilerin istatistiksel değerlendirilmesinde, SPSS 16.0 programı kullanıldı. Olguların HS ve GS analizleri Kaplan-Meier yöntemi ile belirlendi. Değişkenler ile HS ve GS arasındaki ilişkiyi belirlemek için log-rank regresyon analizi, prognostik faktörler ile nüks şekli arasındaki ilişkiyi belirlemek için c2 testi kullanıldı. Oransal Risk Analizi Testinde (Cox Proportional Hazard ) istatistiksel anlaml1lık gösteren prognostik faktörler çok değişkenli analiz ile tekrar değerlendirildi. $\mathrm{P}$ değerinin $<0,05$ olması istatistiksel anlamlılık olarak kabul edildi. Çalışma için Cerrahpaşa Tip Fakültesi Yerel Etik Kurulundan etik kurul onayı alınmıştır. (09/05/2011 tarihli 183890 sayı numaralı) 


\section{BULGULAR}

Demografik Özellikler: Çalışmaya alınan 182 hastanın ortalama takip süresi 24 ay idi. Olguların \%13,7'si kadın (n:25), \%86,3’ ü erkekti (n:157). Ortalama yaşları 58,7 yıl $( \pm 8,38)$ idi. 153 olgunun sigara içtiği $(\% 84,1)$ saptandı. Sigara tüketimi miktar olarak ortalama 48,8 $( \pm 30,5)$ paket/ y1l olarak hesaplandi.

Histopatolojik tipler, evre ve diğer patolojik prognostik faktörler ile ilgili ayrıntılar tablo 1 de verilmektedir.

\begin{tabular}{|c|c|c|}
\hline \multicolumn{3}{|c|}{$\begin{array}{l}\text { Tablo 1:Histopatolojik tipler, evre, patolojik özellikler ve rezek- } \\
\text { siyon durumu }\end{array}$} \\
\hline Parametreler & Hasta sayısı (n) & Yüzde (\%) \\
\hline \multicolumn{3}{|l|}{ Histolojik tip } \\
\hline Squamöz hücreli & 85 & 46,7 \\
\hline Adenokarsinom & 75 & 41,2 \\
\hline Bronkoalveoler & 2 & 1,1 \\
\hline Büyük hücreli & 5 & 2,7 \\
\hline Adenosquamöz & 4 & 2,2 \\
\hline Diğer & 11 & 6,0 \\
\hline \multicolumn{3}{|l|}{ Evre } \\
\hline IA & 4 & 2,2 \\
\hline IB & 18 & 9,9 \\
\hline IIA & 33 & 18,1 \\
\hline IIB & 27 & 14,8 \\
\hline IIIA & 85 & 46,7 \\
\hline IIIB & 15 & 8,2 \\
\hline \multicolumn{3}{|l|}{ Vasküler invazyon } \\
\hline Var & 61 & 33,5 \\
\hline Yok & 69 & 37,9 \\
\hline Bilinmiyor & 52 & 28,6 \\
\hline \multicolumn{3}{|l|}{ Perinöral invazyon } \\
\hline Var & 45 & 24,7 \\
\hline Yok & 85 & 46,7 \\
\hline Bilinmiyor & 52 & 28,6 \\
\hline \multicolumn{3}{|l|}{ Lenfatik invazyon } \\
\hline Var & 101 & 55,5 \\
\hline Yok & 29 & 15,9 \\
\hline Bilinmiyor & 52 & 28,6 \\
\hline \multicolumn{3}{|l|}{ Plevra invazyonu } \\
\hline Var & 44 & 24,2 \\
\hline
\end{tabular}

\begin{tabular}{|l|c|c|}
\hline Yok & 77 & 42,3 \\
\hline Bilinmiyor & 61 & 33,5 \\
\hline Göğüs duvarı invazyonu \\
\hline Var & 6 & 3,3 \\
\hline Yok & 111 & 61,0 \\
\hline Bilinmiyor & 65 & 35,7 \\
\hline Rezeksiyon durumu & 47 & 25,8 \\
\hline NAKT alan & 11 & 6,0 \\
\hline $\begin{array}{l}\text { NAKT sonrası } \\
\text { opere }\end{array}$ & 135 & 74,2 \\
\hline Primer opere & \multicolumn{2}{|l}{} \\
\hline NAKT: neoadjuvan kemoterapi & \\
\hline
\end{tabular}

\section{Opere Olabilmiş Olgularda Nüks Durumu}

Opere olabilen 146 olgunun 80'inde $(\% 54,8)$ nüks saptanmadı, 20 hastada $(\% 13,7)$ lokal nüks, 38 hastada (\%26) uzak metastaz ve 5 hastada $(\% 3,4)$ hem lokal nüks hem de uzak metastaz saptandı, 3 olgunun $(\% 2,1)$ ise nüks durumu bilinmiyordu.

Uzak metastaz saptanan 43 hastanın 3'ünde (\%7) karşı akciğerde, 2 olguda $(\% 4,7)$ sürrenalde, 15 hastada $(\% 34,9)$ beyinde, 9 hastada $(\% 20,9)$ kemikte, 2 hastada $(\% 4,7)$ karaciğerde, 3 hastada (\%7) plevrada, 7 hastada $(\% 16,3)$ diğer bölgelerde ve 2 hastada da $(\% 4,7)$ da multipl metastaz saptandi.

\section{Neoadjuvan Tedavi Grubu:}

Toplam 182 olgunun 47'si $(\% 25,8)$ neoadjuvan tedavi planlanan olgulardı. Bu olguların tümü evre III’tü. Hastaların \%74,5’i evre IIIA iken (n:35); \%25,5’i evre IIIB (n:12) olarak saptand1.

Neoadjuvan tedavi sonrasi 21 hastada $(\% 44,7)$ progresyon, 14 hastada $(\% 29,8)$ stabil hastalık ve 12 hastada $(\% 25,5)$ regresyon görüldü. Olguların 19'una $(\% 40,4)$ neoadjuvan radyoterapi de uygulanmıştı. Cevap oranı \%25,5 (n:12) idi. Bu olguların 11'i $(\% 23,4)$ opere edilebildi. 36 hasta $(\% 76,6)$ ise progresyon, stabil hastalık veya yetersiz regresyon nedeniyle opere olamadı. Opere olan 11 hastanın 8 tanesi adjuvan kemoterapi, 5 tanesi ise adjuvan radyoterapi almıştır. 
Neoadjuvan tedavi uygulanan 47 olguda medyan GS 21,0 $\pm 2,4$ ay (GA;16,3-25,7ay) olarak saptand1. Neoadjuvan tedavi sonrası opere edilebilen olgularda ortalama GS 43,99 $\pm 5,8$ ay (GA;28,6-51,4 ay) olarak saptandı. Neoadjuvan kemoterapi sonrası ameliyat olamayanlarda GS ortalama 20,2 $\pm 1,7$ ay (GA;16,8-23,4ay) olarak saptandı ve bu iki grup arasındaki GS farkı istatistiksel olarak anlamlı bulun$\mathrm{du}(\mathrm{p}=0,005)$. Neoadjuvan olarak tedavi alan 47 olgunun hepsi evre III olduğu için bu grubun GS'si primer opere olan evre III olgularla karşılaştırıldı. Evre III olgularda neoadjuvan veya adjuvan tedavi alan grupların GS süreleri açısından istatistiksel olarak anlamlı bir fark saptanmadı $(\mathrm{p}=0,63)$. (Şekil 1)

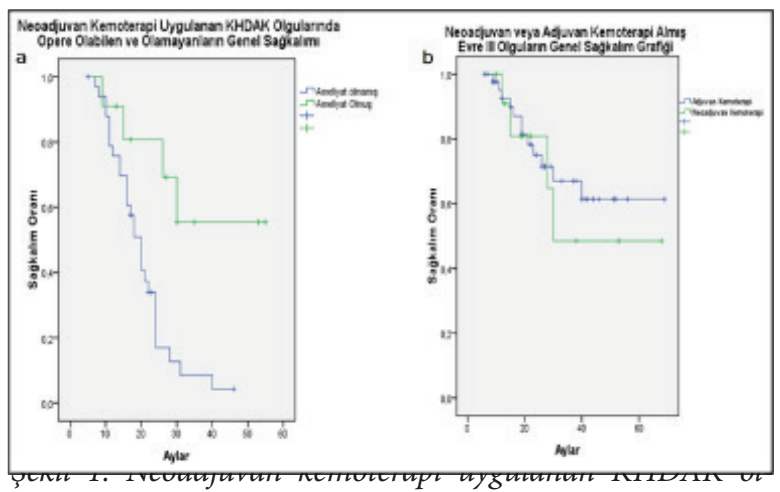

gularında opere olan ve olmayan olguların genel sağkalım sonuçları (a) ve evre-III olguların neoadjuvan ve adjuvan kemoterapi alıp almaması durumunun genel sağkalım (b) sonuçları grafikle şematize edilmiştir.

\section{Adjuvan Tedavi Grubu}

Toplam 182 olgunun 135'i primer cerrahi yapılmış olgulardı. Bu hastaların \%16,3'ü evre I, \%44,4'ü evre II ve \% 37’si evre III aşamasındaydı. Bu olguların 108'i (\%80) cisplatin bazlı adjuvan tedavi almış, 27 olguya (\%20) ise adjuvan kemoterapi uygulanmamıştı. Olguların 38'inde $(\% 28,1)$ adjuvan RT'de uygulanmıştı.

Primer opere edilen hastalarda ortalama HS 37,7 $\pm 2,2$ ay (GA;33,4-42,1 ), GS ise 49,9 $\pm 2,3$ ay (GA;45,4-54,4) ola- rak saptanmıştır. Bu olguların evrelere göre HS ve GS grafikleri aşağıda izlenmektedir. Hastalıksız sağkalım her üç evrede farklıdı ( $\mathrm{p}=0,001)$, GS farkı evre I ve II de anlamlı değilken, evre III te farklıydı ( $\mathrm{p}=0,008)$ (Şekil 2).

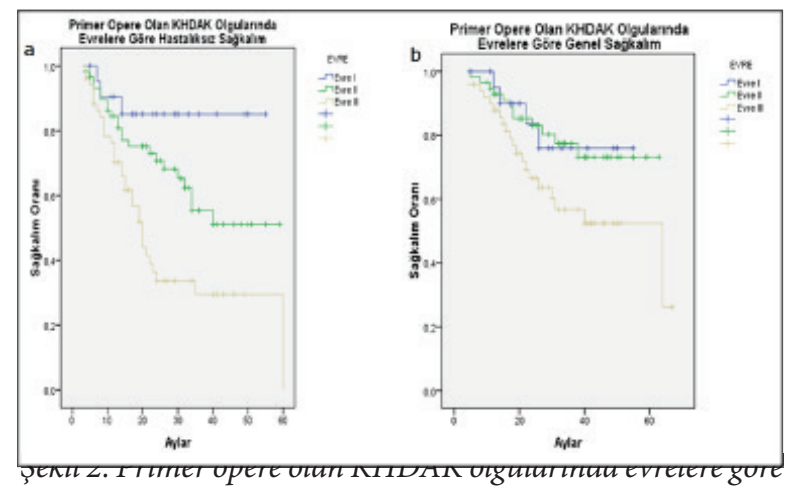

hastalıksız sağkalım (a) ve genel sağkalım (b) grafikle şematize edilmiştir.

Olgular cinsiyet açısından değerlendirildiğinde; HS $(\mathrm{p}=0,733)$ ve $\mathrm{GS}(\mathrm{p}=0,368)$ sürelerinde istatistiksel olarak anlamlı bir fark saptanmamıştır.

Adjuvan kemoterapi alan ve almayan hastaların, hastalıksız ve genel sağkalım süreleri açısından iki grup arasında istatistiksel olarak anlamlı fark saptanmamıştır. (HS için $\mathrm{p}=0,93$; GS için $\mathrm{p}=0,43$ ).

Primer opere olan olgularda adjuvan kemoterapinin etkisine evrelere göre bakıldığında evre I ve II olgularda adjuvan kemoterapi alan ve almayanlar arasında hem HS (Evre I $p=0,61$; Evre II $p=0,22$ ) hem de GS (Evre I p=0,42; Evre II $\mathrm{p}=0,85)$ açısından istatistiksel olarak anlamlı bir fark saptanmadı. Bazı evre III hastalarımıza da ECOG performans skoru düşük olduğu,multipl komorbiditeleri olduğu ya da kemoterapiyi kabul etmedikleri için adjuvan kemoterapi verilemedi. Evre III olgularda ise adjuvan kemoterapi uygulanan olgularda HS ( $\mathrm{p}=0,001)$ ve GS süreleri $(\mathrm{p}<0,001)$ istatistiksel olarak anlamlı olacak şekilde daha iyi saptandı Evre III olguların adjuvan tedavi alıp almamalarına göre HS ve GS grafikleri izlenmektedir (Şekil 3). 


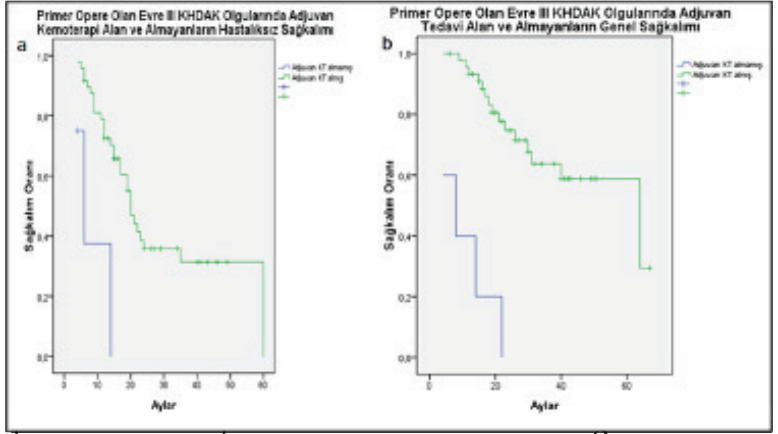

juvan kemoterapi alan ve almayan olguların hastalıksız sağkalım (a) ve genel sağkalımı (b) grafikle şematize edilmiştir.

\section{Adjuvan Radyoterapi Grubu}

Cerrahi sonrası adjuvan radyoterapi alanların HS ve GS süreleri adjuvan radyoterapi almayanlara göre istatistiksel olarak anlamlı ölçüde daha düşük bulunmuştur (HS için $\mathrm{p}=0,010$; $\mathrm{GS}$ için $\mathrm{p}=0,015)$. Ortalama HS radyoterapi alanlarda 29,0 3,9ay (\%95GA:21,4-36,3) almayanlarda $40,5 \pm 2,5$ ay (\%95GA:35,6-45,3), GS ise RT alanlarda 41,1 \pm 4,1ay (\%95GA:32,3-49,9), almayanlarda 52,5 \pm 2 ,4ay (\%95GA:47,9-52,7) olarak saptanmıştır. Adjuvan radyoterapi alan ve almayanların GS grafiği aşağıda izlenmektedir (Şekil 4).

Şekil 4. Prime

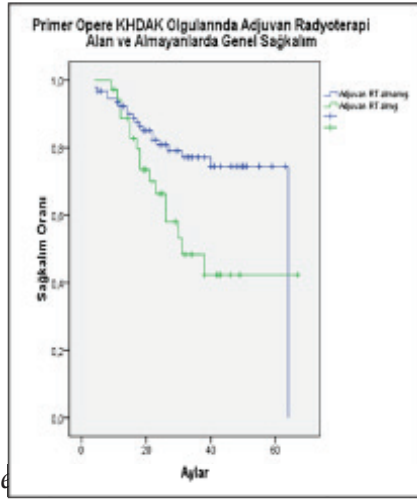

la radyoterapi

alan ve almayan hastaların genel sağkalım sonuçları grafikle şematize edilmiştir.

\section{Patolojik Özelliklerin Prognostik Etkileri}

Tek değişkenli analizde HS için T faktörü ( $\mathrm{p}=0,008)$, vasküler invazyon $(\mathrm{p}=0,009)$ ve göğüs duvarı invazyonu $(\mathrm{p}<$ 0,001) istatistiksel olarak anlamlı bulundu (Tablo 2). GS için $\mathrm{T}$ faktörü $(\mathrm{p}=0,035)$, vasküler invazyon $(\mathrm{p}=0,001)$, perinöral invazyon $(\mathrm{p}=0,049)$ ve göğüs duvarı invazyonu $(\mathrm{p}<0,001)$ istatistiksel olarak anlamlı bulundu (Tablo 2) .

\begin{tabular}{|c|c|c|c|}
\hline \multicolumn{4}{|c|}{$\begin{array}{l}\text { Tablo 2:Patolojik Özelliklerin HS ve GS için Tek Değişkenli } \\
\text { Analizi }\end{array}$} \\
\hline Parametreler & $\begin{array}{l}\text { Ortalama HS } \\
\text { (ay) } \pm \text { SD }\end{array}$ & $\begin{array}{l}\text { Ortalama GS } \\
\text { (ay) } \pm \text { SD }\end{array}$ & $\begin{array}{l}\text { P değeri } \\
\text { (HS/GS }\end{array}$ \\
\hline \multicolumn{4}{|c|}{ TNM 'e göre T Faktörü } \\
\hline $\mathrm{T} 1$ & $32.5 \pm 3.1$ & $42.7 \pm 2.8$ & \\
\hline $\mathrm{T} 2$ & $40.6 \pm 2.8$ & $51.8 \pm 2.7$ & $0.008^{*}(\mathrm{HS})$ \\
\hline $\mathrm{T} 3$ & $33.9 \pm 4.3$ & $47.3 \pm 4.6$ & $0.035^{\star}(\mathrm{GS})$ \\
\hline $\mathrm{T} 4$ & $22.9 \pm 4.4$ & $31.7 \pm 4.8$ & \\
\hline \multicolumn{4}{|c|}{ Adenokarsinom } \\
\hline$(+)$ & $41.3 \pm 3.6$ & $45.3 \pm 3.0$ & 0.590 (HS) \\
\hline$(-)$ & $36.4 \pm 2.8$ & $43.0 \pm 2.7$ & 0.437 (GS) \\
\hline \multicolumn{4}{|c|}{ Skuamöz histoloji } \\
\hline$(+)$ & $39.7 \pm 2.3$ & $44.3 \pm 3.0$ & $0.357(\mathrm{HS})$ \\
\hline$(-)$ & $37.6 \pm 3.1$ & $43.9 \pm 2.7$ & 0.835 (GS) \\
\hline \multicolumn{4}{|c|}{ Vasküler İnvazyon } \\
\hline$(+)$ & $30.7 \pm 3.2$ & $34.4 \pm 3.1$ & $0.009 *(\mathrm{HS})$ \\
\hline$(-)$ & $43.04 \pm 2.9$ & $56.9 \pm 2.6$ & $0.001^{\star}(\mathrm{GS})$ \\
\hline \multicolumn{4}{|c|}{ Perinöral İnvazyon } \\
\hline$(+)$ & $33.3 \pm 3.8$ & $45.3 \pm 4.2$ & 0.100 (HS) \\
\hline$(-)$ & $39.6 \pm 2.6$ & $52.8 \pm 2.6$ & $0.049^{*}(\mathrm{GS})$ \\
\hline \multicolumn{4}{|c|}{ Lenfatik İnvazyon } \\
\hline$(+)$ & $35.9 \pm 2.5$ & $49.3 \pm 2.7$ & 0.144 (HS) \\
\hline$(-)$ & $41.0 \pm 4.1$ & $53.2 \pm 3.9$ & 0,385 (GS) \\
\hline \multicolumn{4}{|c|}{ Plevral İnvazyon } \\
\hline$(+)$ & $29.2 \pm 2.9$ & $43.3 \pm 3.6$ & $0.068(\mathrm{HS})$ \\
\hline$(-)$ & $42.2 \pm 2.8$ & $55.1 \pm 2.7$ & $0.194(\mathrm{GS})$ \\
\hline \multicolumn{4}{|c|}{ Göğüs Duvarı İnvazyonu } \\
\hline$(+)$ & $11.6 \pm 2.6$ & $20.2 \pm 4.3$ & $<0.001^{\star}(\mathrm{HS})$ \\
\hline$(-)$ & $40.9 \pm 2.4$ & $55.1 \pm 2.4$ & $<0.001^{*}(\mathrm{GS})$ \\
\hline
\end{tabular}

Çok değişkenli analizde HS için; T faktörü $(p=0,015)$, 
vasküler invazyon $(\mathrm{p}=0,008)$ ve göğüs duvarı invazyonu $(\mathrm{p}=0,004)$ istatistiksel olarak anlamlı bulundu (Tablo 3$)$.

Genel sağkalım için ise yine T faktörü $(p=0,020)$, vasküler invazyon $(\mathrm{p}=0,041)$ ve göğüs duvarı invazyonu $(\mathrm{p}=0,031)$ istatistiksel olarak anlamlı bulundu (Tablo 3).

\begin{tabular}{|c|c|c|c|}
\hline \multicolumn{4}{|c|}{$\begin{array}{l}\text { Tablo 3: Patolojik özelliklerin HS ve GS için çok değişkenli } \\
\text { analizi }\end{array}$} \\
\hline Patolojik Faktör & $\begin{array}{c}\text { Göreceli } \\
\text { risk } \\
\text { katsayısı }\end{array}$ & $\begin{array}{c}\% 95 \\
\text { güvenilirlik } \\
\text { aralığı }\end{array}$ & $\begin{array}{c}P \\
\text { değeri }\end{array}$ \\
\hline Tümör Çapı & 1.864 & $1.126-3.087$ & $0.015^{\star}$ \\
\hline Vasküler invazyon & 3.494 & $1.388-8.799$ & $0.008^{*}$ \\
\hline Perinöral İnvazyon & 2.025 & $0.871-4.708$ & 0.101 \\
\hline Lenfatik İnvazyon & 0.504 & $0.143-1.776$ & 0.504 \\
\hline Gögüüs Duvarı İnvazyonu & 5.347 & $1.712-16.703$ & $0.004^{*}$ \\
\hline Plevral İnvazyon & 1.100 & $0.466-2.595$ & 0.828 \\
\hline \multicolumn{4}{|c|}{ Patolojik özelliklerin GS için çok değişkenli analizi } \\
\hline Tümör Çapı & 1.548 & $1.070-2.239$ & $0.020^{*}$ \\
\hline Vasküler invazyon & 1.961 & $1.029-3.738$ & $0.041^{*}$ \\
\hline Perinöral İnvazyon & 1.256 & $0.670-2.355$ & 0.477 \\
\hline Lenfatik İnvazyon & 0.114 & $0.431-2.876$ & 0.823 \\
\hline Göğüs Duvarı İnvazyonu & 1.337 & $0.710-2.518$ & $0.031^{*}$ \\
\hline Plevral İnvazyon & 2.210 & $1.393-3.507$ & 0.369 \\
\hline
\end{tabular}

Patolojik özellikler ve nüks paterni arasındaki ilişki ${ }_{\mathrm{x}} 2$ testi ile değerlendirildiğinde ise vasküler invazyon yapmış tümörlerin uzak metastaz yapmaları arasındaki ilişki istatistiksel olarak anlamlı saptanırken $(\mathrm{p}=0,017)$, diğer patolojik özellikler ile nüks şekilleri arasında istatistiksel olarak anlamlı bir ilişki saptanmadı.

\section{TARTIŞMA}

Küçük hücreli dışı akciğer kanserinde adjuvan tedavi konusunda 1995 'ten beri çok sayıda önemli randomize kontrollü çalışma yayınlanmış ve bunlar neticesinde özellikle Evre II ve IIIA da adjuvan kemoterapi standart tedavi haline gelmiştir. Bizim merkezimizde de bu gelişmeler doğrultusunda standart olarak 2004 yılından sonra adjuvan kemoterapi verilmeye başlanmıştır. Bu yüzden retrospektif dosya taraması şeklinde olan çalışmamızda 2005 yılı ve sonrasındaki olguları taradık.

Çalışmamızda dosya bilgilerini aldığımız 182 olgunun 47'si neoadjuvan tedavi uygulanan, geri kalan 135'i ise primer opere olup adjuvan tedavi alarak veya almadan izlenen hastalardı. Bu olgular neoadjuvan grup ve adjuvan grup olarak iki ayrı kategoride değerlendirildi.

Olgularımızın \%86’sı erkek; ortalama yaşı 59'du. Akciğer kanseri ile ilgili birçok çalışma ile yaş ve cinsiyet dağılımı benzerdi. Sigara içen hastalar, bizim çalışma grubumuzda \%84'lük bir kısmı oluşturuyordu.

En sık görülen histolojik tip skuamoz hücreli karsinom iken $(\% 46,7)$, ikinci sırada adenokarsinom $(\% 41,2)$ geliyordu. Primer opere olan 135 hastanın \%16.3'i evre I, $\% 44,4$ 'ü evre II ve \% 37'si evre III idi. Hastalıksız sağkalım açısından evre I, evre II ve evre III’teki hastaların sağkalım süreleri birbirinden anlamlı derecede farklı bulunmuşken ( $p=0,001)$, GS açısından ise sadece evre III; evre I ve II ye göre istatistiksel olarak anlamlı ölçüde kısa bulunmuş; evre I ve II arasında istatistiksel olarak anlamlı fark saptanmamıştır ( $\mathrm{p}=0,081)$. ANITA çalışmasında bizim çalışmamıdaki gibi evre III'ün GS'si evre I ve II ye göre daha düşük bulunmuştur. ${ }^{2}$

Adjuvan kemoterapi ile ilgili 2018 yılında Chen Y. Ve arkadaşları 920 çalışmayı taramış ve bunlar ile ilgili meta-analiz yayınlanmışlardır. Bu meta-analizde cisplatin bazlı adjuvan kemoterapi alan erken evre hastalarda 2 yıllık sağkalım avantajı $\% 3$ ve 5 yıllık sağkalım avantajı $\% 5$ civarında bulunmuştur (p:0,08). ${ }^{3}$

Arbour KC ve arkadaşları moleküler alt tiplere göre adjuvan kemoterapinin yararlı olacağını göstermişlerdir. ${ }^{4}$ ECOG, ALPI, BLT, JCOGTJ9304 çalışmaları KHDAK 'de adjuvan kemoterapinin yararını gösteremeyen çalışmalardır. ${ }^{5-7}$ Adjuvan kemoterapinin yararını gösteren IALT, JBR 10, ANITA çalışmalarında ve LACE-Vinorelbin meta-analizlerinde ise bu yarar evre II ve III olgularda görül- 
mektedir. ${ }^{2,8-11}$ CALGB 9633 çalışmasında evre IB olgularda saptanan adjuvan tedavi yararı 5 yıllık takip sonuçlarında kaybolmuştur. ${ }^{12}$ Japonyada yapılan adjuvan UFT çalışmalarında Evre IB aşamasında gösterilen yarar batı toplumlarında çok kabul görmemektedir. Bu nedenle Evre IB hastalıkta günümüzde adjuvan kemoterapinin yararı tartışmalıdır. Evre IB olgularda hasta özelliklerine ve tümör çapı, evresi ve vasküler invazyon olup olmaması gibi tümör özelliklerine bakılarak adjuvan tedavi uygulamasına karar verilmektedir. ${ }^{13-14}$

Bizim çalışmamızda da primer cerrahi yapılıp adjuvan kemoterapi alan ve almayan grup karşılaştırıldığında tüm evreler birlikte değerlendirildiğinde adjuvan tedavinin yararı gösterilememiştir ( $H S$ için $p=0,93$; GS için $p=0,43$ ). Evreler ayrı ayrı değerlendirildiğinde ise Evre I ve II'de yarar gösterilemezken; evre III hastalarda hem HS ( $\mathrm{p}=0,001)$ hem de GS sürelerinde $(\mathrm{p}<0,001)$ adjuvan kemoterapi lehine istatistiksel olarak anlamlı bir artış saptanmıştır. Adjuvan tedavinin etkinliği cinsiyete ve histolojik tipe göre fark göstermemektedir.

Çalışmamızda evre II olgularda yarar gösterilememesinin sebebi bu evrede adjuvan tedavi yararının göreceli olarak daha az olması ve bizim retrospektif analizimizdeki hasta sayısının bu farkı gösterecek güçte olmaması olabilir.

Adjuvan radyoterapi lokal nüksü azaltmakla birlikte sağkalım avantajı gösterdiğine dair pozitif sonuçlanan çalışma olmadığı için günümüzde standart bir tedavi değildir. ${ }^{14-16}$ Bizim çalışmamızda da adjuvan radyoterapi alanların genel $(p=0,015)$ ve hastalıksız sağkalım süreleri $(p=0,01)$ almayanlara göre daha kısa bulunmuştur. Bunun nedeni adjuvan radyoterapi alması gereken hastaların daha ileri evre ve muhtemelen cerrahi sınır ve N2 pozitifliği olan hastalar olması ve radyoterapi, kemoterapi gibi iki farklı modalite kullanıldığında tedavi toksisitesinin artması nedeniyle artan mortalite olabilir.

Çalışmamızdaki neoadjuvan kemoterapiye cevap oranla- r1 ve opere olabilen hasta yüzdesi diğer birçok çalışmaya göre düşüktür. Neoadjuvan tedavi alan 47 hastanın hepsi evre III olgular olup, genel sağkalım açısından primer opere olan evre III hastalarla karşılaştırıldığında bu iki grup arasında anlamlı sağkalım farkı saptanmaması fakat mediastinal evresi gerileyip opere olabilen 11 hastanın sağkalım sürelerinin opere olamayanlara göre istatistiksel olarak anlamlı derecede uzun bulunması diğer bir çok neoadjuvan çalışma verisi ile uyumludur. ${ }^{17-18}$

Tümör çapı CALGB9633 çalışmasının subgrup analizinde analizinde hem HS hem de GS açısından anlamlı bulunmuş. Daha sonra vasküler invazyon ve tümör çapı birlikte birçok çalışmada hem HS hem de GS artışı ile ilişkilendirilmiştir. ${ }^{19-21}$ Gögüs duvarı invazyonu genellikle evre 3 hastalarda çalışılmış ve Chiappetta $M$ ve arkadaşlarının yaptığı çalışmada invazyon derinliğinin sağkalıma etkisi bulunmuştur. ${ }^{22} \mathrm{Bu}$ çalışmada da tümörün patolojik prognostik özellikleri değerlendirildiğinde, hem HS hem de GS açısından önemli olan prognostik faktörler T faktörü, gögüs duvarı invazyonu ve vasküler invazyondur. Ayrıca vasküler invazyonun da uzak metastaz ile anlamlı ilişkisinin bulunması çalışma sonuçlarımız açısından önemlidir. Çalışmamız retrospektif ve vaka sayısı kısıtlı tek merkezli bir çalışmadır. Neoadjuvan ve adjuvan tedavilerin yararının evrelere göre gösterilebilmesi için pek çok randomize kontrollü çalışma yapılmış ve yapılagelmektedir. Bu çalışma bizim tek merkez verilerimizi göstermesi ve evrensel verilere uygunluğu konfirme etmemiz açısından önemlidir.

\section{SONUÇ}

Çalışmamızda adjuvan kemoterapinin evre I ve II hastalarda HS ve GS açısından anlamlı yararı bulunmamıştır. Evre III olgularda ise adjuvan kemoterapi ile HS ve GS sürelerinde istatistiksel olarak anlamlı ölçüde artış sağlandığg saptanmıştır.

Neoadjuvan tedavi verilen hastaları aynı evredeki primer cerrahi yapılan olgular ile karşılaştırdığımızda anlamlı 
sağkalım süresi farkı bulunmamıştır; fakat neoadjuvan tedaviye cevap verip opere olabilen yaklaşık dörtte bir vakada opere olamayan diğer vakalara göre anlamlı sağkalım artı̧ı gözlenmiştir.

Tümörlerin vasküler invazyon yapmış olması, tümör boyutunun büyük olması ve göğüs duvarı invazyonu olması prognozu kötü yönde etkileyen patolojik özellikler olarak saptanmıştır. Vasküler invazyonun tümörlerin uzak metastaz riskini arttıran bir faktör olduğu bulunmuştur.

Küçük hücreli dışı akciğer kanserinde tedavi modaliteleri günden güne ilerlemekte olup farklı noktalara 1şık tutacak daha büyük çalışmalar sürmektedir.

\section{Etik Kurul Onayı}

Cerrahpaşa Tip Fakültesi Yerel Etik Kurulu (09/05/2011 tarihli 183890 sayı numaralı) 


\section{Sakarya Tip Dergisi 2020;10(3):450-458}

CENGIZZ ve Ark., Akciğer Kanseri ve Kemoterapi

\section{Kaynaklar}

1. Midthun DE,Lilenbaum RC, Schild SE,Vora SR et al Overview to Initial Treatment and Prognosis of Lung Cancer /online available at http://www Up to Date com. (the data uploaded on October 2019)

2. Douillard JY,Rosell R,De Lena M,Carpagnano F,Ramlau R,Gonzales Larriba JL et al.Adjuvant Vinorelbine Plus Cisplatin Versus Observation in Patients With Completely Resected Stage IB-IIIA Non-small Cell Lung Cancer (Adjuvant Navelbine International Trialist Association [ANITA]):A Randomised controlled trial. Lancet 2006; 7:719-27.

3. Chen Y., Peng X., Zhou Y., Xia K., Zhuang W. Comparing the benefits of chemoradiotherapy and chemotherapy for resectable stage III A/N2 non-small cell lung cancer: a meta-analysis. World J Surg Oncology 2018 Jan 16;16(1):8. doi: 10.1186/s12957-018-1313-x.

4. Arbour KC., Riely, GJ. Systemic Therapy for Locally Advanced and Metastatic NonSmall Cell Lung Cancer: A Review. JAMA 2019 Aug 27;322(8):764-774. doi: 10.1001/ jama.2019.11058.

5. Bradbury P., Sivajohanathan D., Chan A., Kulkarni S., Ung Y., Ellis PM. Postoperative adjuvant systemic therapy in completely resected non-small-cell lung cancer: a systematic review. Clin Lung Cancer. 2017 May; 18(3):259-273.e8. doi: 10.1016/j.cllc.2016.07.002

6. Timothy F Mott. Lung Cancer: Management. FP Essent 2018 Jan;464:27-30.

7. Tada H,Tsuchiya R,Ichinose Y,Koike T,Nishizawa N,Nagai K et al. A Randomised Trial Comparing Adjuvant Chemotherapy Versus Surgery Alone for Completely Resected pN2 Non-small Cell Lung Cancer. (JCOG9304).Lung Cancer 2004;43:167-73.

8. Burdett S., Pignon JP., Tierney J., Tribodet H., Stewart L., Le Pechoux, Higgins JP. (2015). Adjuvant chemotherapy for resected early-stage non-small cell lung cancer. Cochrane Database of Systematic Reviews 3, Mar 2015 2;:CD011430. doi: 10.1002/14651858.CD011430.

9. Arriagada R,Dunant A, Pignon JP,Bergman B,Chabowski M et al.Long-Term Results of the International Adjuvant Lung Cancer Trial (IALT) Evaluating Adjuvant Cisplatin-Based Chemotherapy in Resected Lung Cancer .J Clin Onc 2010;28:35-42.

10. Winton T, Livingston R,Johnson D, Rigas J,Johnston M,Butts C et al. Vinorelbine plus Cisplatin vs. Observation in Resected Non-Small-Cell Lung Cancer N Eng J Med 2005;352:258997.

11. Drąg-Zalesińska M., Saczko J., CHOROMAŃSKA A., Szewczyk A., Rembiałkowska N., Kulbacka J., Rzechonek A. Cisplatin and vinorelbine-mediated electrochemotherapeutic approach against multidrug resistant small cell lung cancer (H69AR) in vitro. Anticancer research, 2019 Jul;39(7):3711-3718. doi: 10.21873/anticanres.13519.

12. Strauss GM,Herndon JE,Maddaus MA,Johnstone DW,Johnson EA,Harpole DH et al.Adjuvant Paclitaxel Plus Carboplatin Compared with Observation in Stage IB Non-Small-Cell Lung Cancer:CALGB 9633 with the Cancer and Leukemia Group B,Radiation Therapy Oncology Group, and North Central Cancer Treatment Group Study Groups.J Clin Oncol 2008;28:5043-51.
13. Wakeam E., Acuna SA., Leighl NB., Giuliani ME., Finlayson SRG., Varghese, TK., Darling GE. Surgery versus chemotherapy and radiotherapy for early and locally advanced small cell lung cancer: a propensity-matched analysis of survival. Lung Cancer. 2017 Jul;109:78-88. doi: 10.1016/j.lungcan.2017.04.021.

14. National Comprehensive Cancer network (NCCN) Clinical Practice Guidelines in Oncology available at http://www.nccn.org/professionals/physican_gls/__guideline.asp (accessedMay 12,2009).

15. Burdett S., Rydzewska L., Tierney J., Fisher D., Parmar MK., Arriagada R., Le Pechoux C. Postoperative radiotherapy for non-small cell lung cancer. Cochrane database of systematic reviews 2016 Oct 11;10(10):CD002142. doi: 10.1002/14651858.CD002142.pub4.

16. Brandt WS., Yan W., Leeman, JE., Tan KS., Park BJ., Adusumilli PS., Rimner A. (2018). Postoperative radiotherapy for surgically resected ypN2 non-small cell lung cancer. Ann Thorac Surg 2018 Sep;106(3):848-855. doi: 10.1016/j.athoracsur.2018.04.064.

17. Betticher DC, Hsu Schmitz SF, Tötsch M,Hansen E,Joss C,von Briel C et al. Prognostic Factors Affecting Long-Term Outcomes in Patients with Resected Stage IIIA pN2 Non-small Cell Lung Cancer : 5-year Follow-up of a Phase II Study. British J Cancer 2006;94:10991106.

18. Albain KS,Rusch VW,Crowley JJ,Rice TW,Turrisi AT, Weick JK et al.Concurrent Cisplatin/ Etoposide Plus Chest Radiotherapy Followed by Surgery for Stages IIIA (N2) and IIIB Nonsmall Cell Lung Cancer:Mature Results of Southwest Oncology Group Phase II Study 8805. J Clin Oncol 1995; 13:1880-92.

19. Schuchert MJ,Schumacher L,Kilic A,Close J,Landereneau JR,Pennathur A et al.Impact of Angiolympatic and Pleural Invasion on Surgical Outcomes for Stage I NSCLC. Ann Thorac Surg 2011;91:1059-65.

20. Hsu CP., Hsia JY., Chang GC., Chuang CY., Shai SE., Yang SS. Et al Surgical-pathologic factors affect long-term outcomes in stage IB ( heterogeneous disease. J Thorac Cardiovasc Surg. 2009 Aug;138(2):426-33. doi: 10.1016/j. jtcvs.2008.12.035.

21. Shimada Y., Saji H., Kato Y., Kudo Y., Maeda J., Yoshida K., Ohira T. The frequency and prognostic impact of pathological microscopic vascular invasion according to tumor size in non-small cell lung cancer. Chest. 2016 Mar;149(3):775-85. doi: 10.1378/chest.15-0559.

22. Chiappetta M., Nachira D., Congedo MT., Meacci E., Porziella V., Margaritora S. NonSmall Cell Lung Cancer with Chest Wall Involvement: Integrated Treatment or Surgery Alone?. Thorac Cardiovasc Surg. 2019 Jun;67(4):299-305. doi: 10.1055/s-0038-1632363. 